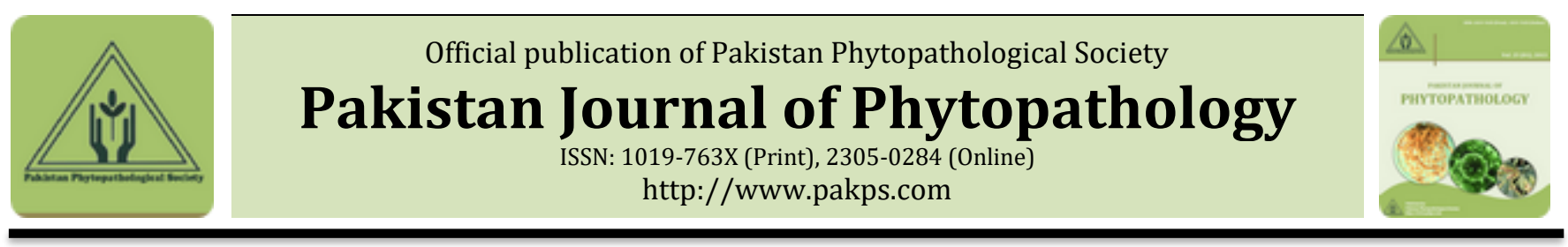

\title{
AGRONOMIC MANAGEMENT OF BACTERIAL LEAF BLIGHT OF RICE (ORYZA SATIVA L.) DISEASE AND YIELD ENHANCEMENT THROUGH DIFFERENT COMBINATIONS OF NITROGEN AND POTASH DOSES
}

\author{
aWaqas Hamid, aMuhammad A. Rashid, bAmer Habib*, aNadeem Akbar, cEjaz Ashraf \\ a Department of Agronomy, University of Agriculture, Faisalabad, Pakistan. \\ ${ }^{b}$ Department of Plant Pathology, University of Agriculture, Faisalabad, Pakistan. \\ ${ }^{c}$ Institute of Agricultural Extension and Education, University of Agriculture, Faisalabad, Pakistan.
}

\begin{abstract}
A B S T R A C T
This research trial was conducted at Rice Research Institute, Kala Shah Kaku, during kharif 2010, to assess the influence of nitrogen $(\mathrm{N})$ and potash $(\mathrm{K})$ on the incidence and severity of Bacterial leaf blight of rice (BLB) (Oryzae sativa L.). The experiment was laid out in a Randomized Complete Block Design in factorial arrangement with three replications using net plot size of $2.25 \mathrm{~m} \times 6.0 \mathrm{~m}$. The experiment was comprised of $0,75,100,125 \mathrm{~kg} \mathrm{~N} \mathrm{ha}^{-1}$ and 0,50 , $75,100 \mathrm{~kg} \mathrm{~K} \mathrm{ha}^{-1}$. Thirty days old nursery of Super Basmati was transplanted manually in puddle field. Data on disease severity and yield parameters of rice were recorded using standard procedures. Yield parameters were affected significantly by various combinations of $\mathrm{N} \& \mathrm{~K}$. In case of BLB, minimum diseased leaf area (15.76 \% DLA) was observed where $\mathrm{N}$ alone was applied @ $75 \mathrm{~kg} \mathrm{ha}^{-1}$ in contrast to $125 \mathrm{~kg} \mathrm{~N}+50 \mathrm{~kg} \mathrm{~K} \mathrm{ha}^{-1}$ which showed maximum DLA (43.17\%). Highest paddy yield of $4.32 \mathrm{t} \mathrm{ha}^{-1}$ was recorded where rice was fertilized @ $75 \mathrm{~kg} \mathrm{~N}+100 \mathrm{~kg} \mathrm{~K} \mathrm{ha}^{-1}$, while the minimum paddy yield of $2.40 \mathrm{t} \mathrm{ha}^{-1}$ was obtained where only $75 \mathrm{~kg} \mathrm{~K} \mathrm{ha}^{-1}$ was applied. Optimum fertilization @ 75 $\mathrm{kg} \mathrm{N}+100 \mathrm{~kg} \mathrm{~K} \mathrm{ha}^{-1}$ improved the harvest index value up to $20.32 \%$. Minimum harvest index of $15.61 \%$ was obtained where $\mathrm{K}$ alone was applied at the rate of $100 \mathrm{~kg} \mathrm{ha}^{-1}$. Maximum gross income (Rs.154652 ha-1), net return (Rs.154652 ha-1), and BCR (1.32) were obtained where rice crop was fertilized @ 75 kg N and $100 \mathrm{~kg} \mathrm{~K} \mathrm{ha}^{-1}$.
\end{abstract}

Keywords: Rice BLB, Potash, Nitrogen, yield attributes.

\section{INTRODUCTION}

Rice is an important cereal crop and nearly more than half population of the world subsists on it. It is the third largest crop in Pakistan after wheat and cotton. Rice is grown on an area of 2.88 million hectares with a total production of 6.88 million tons an average yield of $2.38 \mathrm{t}$ ha $^{-1}$. It accounts for $4.4 \%$ of value contributed in agriculture and $0.9 \%$ in GDP (GOP, 2010).

Despite higher potential, average yield of rice in Pakistan is $2.38 \mathrm{t} \mathrm{ha}^{-1}$ which is lower than most of the countries of world. This low production is attributed to delayed Submitted: February 24, 2017

Revised: June 07, 2018

Accepted for Publication: June 20, 2018

* Corresponding Author:

Email: amer.habib@uaf.edu.pk

(C) 2017 Pak. J. Phytopathol. All rights reserved. sowing, low plant population, imbalance fertilizer use and disease attack especially Rice blast and Bacterial leaf blight (Chaudhary et al., 2009, Ou, 1985). The bacterial leaf blight causes great losses wherever rice is grown. The disease is reported to induce $50 \%$ or even greater losses in severe cases. Losses in the tropical Asia varied 2-74\% depending upon location, weather conditions, crop stage and cultivar (Davierwala et al., 2001).

Much work has been done to control the diseases through chemicals and antibiotics (Mary and Mathew, 1983). Effective control of the disease had not been achieved by chemical methods (Reissing et al., 1986). Under prevailing conditions commercial resistant varieties are generally scarce and current varieties are susceptible to these diseases thus reducing their potential due to disease attack. Cultural practices such as fertilizer rate, sowing time and irrigation etc. played an 
important role for the management of these diseases (Kurschner et al., 1992, Long et al., 2000 and Myint et al., 2007). So, there is a need to emphasize over the cultural techniques for the effective management of these diseases.

The plant diseases are influenced by specific genotype, fertilizer input and climatic conditions, which vary yearly (Krupinsky et al., 2007). Different plant nutrients and their balanced use play a significant role in reducing pest and disease infestation, which results in higher returns through enhanced yields and better quality (Magnen, 2008). The cultural control may include the alteration of $\mathrm{N}$ and $\mathrm{K}$ levels, and investigating the appropriate levels for the control of these diseases. Optimum fertilization of $\mathrm{N}$ and $\mathrm{K}$ induces tolerance in plants and minimize the disease incidence.

It is a fact that excessive $\mathrm{N}$ application predispose plants to disease caused by obligatory parasitic pathogens (Gothoskar et al., 1995). Sharma (2007) reported that excessive use of $\mathrm{N}$ fertilizers could result in more leaf growth that was over succulent and more susceptible to certain diseases. It was found that BLB incidence considerably increased by enhancing the rate of $\mathrm{N}$ fertilizer (Matho and Ganguly, 2001).

The role of $\mathrm{K}$ is very important regarding the disease control. The potassium aggregate increases the vigor and the resistance of the plant to stress. It fortifies the straw, enhances the quality of grains and helps the transfer of starch, sugars and oils. K strengthens the plant leaf cells and $\mathrm{K}$ deficiency in leaf cells makes them weak and susceptible to secondary fungal infection (Harris, 1997). Sufficient K nutrition increases cell cuticle thickness, cell wall strength and production of phenols that ultimately implant resistance in crops (Jayasena and Brennan, 2007). Potassium fertilization greatly affected panicle blast development, the response being significantly linear and negative with increasing levels of $\mathrm{K}_{2} \mathrm{O}$ (Prabhu et al,, 1999). Thus disease incidence can be lowered by high $K$ levels (Tajani et al., 1993; William et al., 2001). However, in Pakistan K use is only about $2 \mathrm{~kg} \mathrm{ha}^{-1}$ (GOP. 2010).

\section{MATERIALS AND METHODS}

The research trial was conducted to study the influence of $\mathrm{N}$ and $\mathrm{K}$ levels on the severity of BLB at Rice Research Institute (RRI), Kala Shah Kaku, Lahore during the year 2010. The experiment was laid out in a Randomized Complete Block Design in factorial arrangement with three replications using net plot size of $2.25 \mathrm{~m} \times 6.0 \mathrm{~m}$. The experiment was comprised of $0,75,100,125 \mathrm{~kg} \mathrm{~N}$ ha $^{-1}$ and $0,50,75,100 \mathrm{~kg} \mathrm{~K} \mathrm{ha}^{-1}$. Thirty days old nursery of Super Basmati was transplanted manually in puddle field on $16^{\text {th }}$ July 2010 . Whole of the phosphorus @ $75 \mathrm{~kg}$ $\mathrm{P}$ ha $^{-1}$ and Zinc was applied at the time of soil preparation. Whole of the $\mathrm{K}$ was added to the plots just before transplanting of nursery according to respective treatments. $\mathrm{N}$ was added in two splits i.e. $1 / 2$ was applied just after transplantation of nursery and $1 / 2$ half dose was applied 30 DAT. Machete 60EC was applied (2 t/ha) to control weeds just after four days of transplanting. The remaining (fallow) weeds were controlled manually. ZnSO4 (35\%) was applied @ 12.5 $\mathrm{kg} / \mathrm{ha}$ at 12 DAT. Rice was inoculated with Xanthomonas oryzae pv. oryzae following clipping method at tillering and heading stage. Data regarding BLB incidence was analyzed according to the following disease rating scales developed by IRRI (IRRI system, 1996) Table 1.

Table 1. Disease rating scale for BLB of rice.

\begin{tabular}{ccc}
\hline Percent area & Response & Ranking \\
\hline $0 \%$ & Highly resistant & 0 \\
\hline $0-1 \%$ & Resistant & 1 \\
\hline $1-5 \%$ & Moderately resistant & 3 \\
\hline $6-25 \%$ & Moderately susceptible & 5 \\
\hline $26-50 \%$ & Susceptible & 7 \\
\hline $51-100 \%$ & Highly susceptible & 9 \\
\hline
\end{tabular}

Percent disease incidence will be calculated according to the formula as follows:

$$
\text { Disease Incidence (\%) } \frac{\text { Total lesion area }}{\text { Total leaf length }} \times 100
$$

The data obtained were analyzed statistically by using Fisher analysis of variance technique and difference among treatment means was compared by using least significant difference test (LSD) at 5\% probability level. The differences were only considered when significant at $\mathrm{p}<0.05$.

\section{RESULTS AND DISCUSSION}

Disease incidence (\%): Data regarding the appearance of 
BLB of rice is presented in Table 2. Data revealed that interaction of $\mathrm{N}$ and $\mathrm{K}$ regarding the incidence of $\mathrm{BLB}$ of rice was statistically significant. The $\mathrm{N}$ and $\mathrm{K}$ also had significant effect on incidence of BLB.

Table 2. Effect of $\mathrm{N}$ and K levels on BLB percentage leaf infection.

\begin{tabular}{cccccc}
\hline \multirow{2}{*}{ Treatment } & $\begin{array}{c}\text { N0 } \\
0 \mathrm{~kg} / \mathrm{ha}\end{array}$ & $\begin{array}{c}\mathrm{N} 1 \\
75 \mathrm{~kg} / \mathrm{ha}\end{array}$ & $\begin{array}{c}\mathrm{N} 2 \\
100 \mathrm{~kg} / \mathrm{ha}\end{array}$ & $\begin{array}{c}\mathrm{N} 3 \\
125 \mathrm{~kg} / \mathrm{ha}\end{array}$ & Mean \\
\hline $\mathrm{K} 0,0 \mathrm{~kg} / \mathrm{ha}$ & $35.27 \mathrm{a}$ & $15.76 \mathrm{c}$ & $25.89 \mathrm{~b}$ & $31.06 \mathrm{ab}$ & $26.99 \mathrm{~b}$ \\
\hline $\mathrm{K} 1,50 \mathrm{~kg} / \mathrm{ha}$ & $30.20 \mathrm{~b}$ & $24.13 \mathrm{~b}$ & $27.82 \mathrm{~b}$ & $43.17 \mathrm{a}$ & $31.33 \mathrm{a}$ \\
\hline $\mathrm{K} 2,75 \mathrm{~kg} / \mathrm{ha}$ & $27.17 \mathrm{a}$ & $23.07 \mathrm{a}$ & $26.33 \mathrm{a}$ & $27.00 \mathrm{a}$ & $25.89 \mathrm{~b}$ \\
\hline $\mathrm{K} 3,100 \mathrm{~kg} / \mathrm{ha}$ & $28.10 \mathrm{a}$ & $21.22 \mathrm{~b}$ & $22.33 \mathrm{~b}$ & $33.73 \mathrm{a}$ & $26.35 \mathrm{~b}$ \\
\hline Mean & $30.18 \mathrm{~b}$ & $21.05 \mathrm{~d}$ & $25.59 \mathrm{c}$ & $33.74 \mathrm{a}$ & \\
\hline
\end{tabular}

LSD value for $\mathrm{N}=3.41$

LSD value for interaction $=6.837$

LSD value for $\mathrm{K}=3.41$

Percent diseased leaf area (\% DLA) increased significantly when assessed in the interaction of $\mathrm{N}$ and $\mathrm{K}$. At zero kg K level, the zero $\mathrm{kg} \mathrm{N}^{-1} \mathrm{~h}^{-1}$ and $125 \mathrm{~kg} \mathrm{~N}^{-1}$ produced statistically similar percent diseased leaf area (\% DLA) i.e. 35.27 and $31.06 \%$ respectively, followed by $25.89 \%$ at $100 \mathrm{~kg} \mathrm{~N} \mathrm{ha}^{-1}$, and the minimum percent diseased leaf area (\% DLA) of $15.76 \%$ was obtained at $75 \mathrm{~kg} \mathrm{~N} \mathrm{ha}^{-1}$. The maximum percent diseased leaf area (DLA) of $43.17 \%$ was attained at $125 \mathrm{~kg} \mathrm{~N} \mathrm{ha}^{-1}$ at $50 \mathrm{~kg}$ $\mathrm{K}$ level, whereas 0,75 and $100 \mathrm{~kg} \mathrm{~N} \mathrm{ha}^{-1}$ produced statistically at par percent diseased leaf area (\% DLA) i.e. $30.20,24.13$ and $27.28 \%$ respectively. Percent diseased leaf area (\% DLA) showed no response to $\mathrm{N}$ fertilization from $0-125 \mathrm{~kg} \mathrm{~N} \mathrm{ha}^{-1}$ at $75 \mathrm{~kg} \mathrm{~K} \mathrm{ha}^{-1}$. On the other hand, at $100 \mathrm{~kg} \mathrm{~K}$ level, the zero and $125 \mathrm{~kg} \mathrm{~N} \mathrm{ha}^{-1}$ gave highest percent diseased leaf area (\% DLA) of 28.10 and 33.73 $\%$, followed by $75 \mathrm{~kg} \mathrm{~N} \mathrm{ha}^{-1}$ and $100 \mathrm{~kg} \mathrm{~N} \mathrm{ha}^{-1}$ which gave 21.22 and $22.33 \%$ DLA respectively.

The \% DLA showed a parabolic trend to various $\mathrm{N}$ fertilization levels at zero $\mathrm{kg} \mathrm{K} \mathrm{ha}^{-1}$ i.e. more where no $\mathrm{N}$ was applied, decreased by $55 \%$ when $\mathrm{N}$ application was made at the rate of $75 \mathrm{~kg} \mathrm{~N}^{-1}$ and again increased by 11.9-26.6 \% at 100-125 $\mathrm{kg} \mathrm{N} \mathrm{ha}^{-1}$ against control (0 kg N $\mathrm{ha}^{-1}$ ). At $50 \mathrm{~kg} \mathrm{~K}$ level, the percent diseased leaf area remained unaffected with $\mathrm{N}$ fertilization from zero to100 $\mathrm{kg} \mathrm{N} \mathrm{ha-1}$, however percent diseased leaf area (\% DLA) reaches at its maximum at $125 \mathrm{~kg} \mathrm{~N} / \mathrm{ha}$. On the other hand, percent diseased leaf area (\% DLA) remained unaffected with any rate of $\mathrm{N}$ at $75 \mathrm{~kg} \mathrm{~K}$ level. The percent diseased leaf area (\% DLA) once again showed a parabolic trend at $100 \mathrm{~kg} \mathrm{~K}$ level where comparatively high percent diseased leaf area (\% DLA) was recoded in treatment with out $\mathrm{N}$ fertilization and it decreased by $24.48 \%$ at $75 \mathrm{~kg} \mathrm{~N}$ level. A further increase of $\mathrm{N}$ fertilization by $25 \mathrm{~kg} \mathrm{~N}^{-1}$ (i.e. $100 \mathrm{~kg} \mathrm{~N} \mathrm{ha}^{-1}$ ) did not contributed any way to percent diseased leaf area (\% DLA). However when $\mathrm{N}$ fertilization was increased upto $125 \mathrm{~kg} \mathrm{~N} \mathrm{ha}^{-1}$ the percent diseased leaf area (\% DLA) again increased by $33 \%$. Percent diseased leaf area (\% DLA) varied differently in relation to $\mathrm{N}$ fertilization at different $\mathrm{K}$ rates. Irregular trend was seen at different $\mathrm{K}$ levels however $75-100 \mathrm{~kg} \mathrm{~N}^{-1}$ gave lower percent diseased leaf area (\% DLA) as compared to control and $125 \mathrm{~kg} \mathrm{~N} \mathrm{ha}^{-1}$. Based on results it was deduced that BLB could be minimized by a better combination of $\mathrm{N}$ and $\mathrm{K}$ rather to apply these nutrients in a haphazard manner. So for better management of disease a balanced combination of $\mathrm{N}$ and $\mathrm{K}$ should be applied. Prabhu et al., (1999) also suggested that K:N ratio is more important then the effect of each nutrient in blast development.

Paddy yield ( $t$ ha $^{-1}$ ): Paddy yield enhanced significantly when assessed by the interaction of $\mathrm{N}$ and $\mathrm{K}$. Results showed (Table 3 ) that at zero to $50 \mathrm{~kg} \mathrm{~K} \mathrm{ha}^{-1}$ the yield depicted similar trend to $\mathrm{N}$ fertilization. The minimum yield was recorded at zero $\mathrm{kg} \mathrm{N} \mathrm{ha}^{-1}$ and an increase of $32-36 \%$ was recorded at $75 \mathrm{~kg} \mathrm{~N} \mathrm{ha}^{-1}$. A further increase of $25 \mathrm{~kg} \mathrm{~N}$ ha $^{-1}$ did not contribute to yield, whereas increase in $\mathrm{N}$ fertilization up to $125 \mathrm{~kg} \mathrm{~N}$ resulted in decline of yield.

Treatments with 75 and $100 \mathrm{~kg} \mathrm{~K} \mathrm{ha}^{-1}$ showed similar trend to $\mathrm{N}$ fertilization where the minimum yield was recorded in treatment with zero $\mathrm{kg} \mathrm{N}^{-1}$, and an increase of 41-44\% was recorded when applied with 75 $\mathrm{kg} \mathrm{N} \mathrm{ha}^{-1}$. After $75 \mathrm{~kg} \mathrm{~N} \mathrm{ha}^{-1}$ every increase in $25 \mathrm{~kg} \mathrm{~N}$ resulted in decline of yield and this decline was recorded $7-12 \%$ at $100 \mathrm{~kg} \mathrm{~N}$ and $18-19 \%$ at $125 \mathrm{~kg} \mathrm{~N}$ as compared with $75 \mathrm{~kg} \mathrm{~N} \mathrm{ha}^{-1}$. 
Table 3. Effect of $\mathrm{N}$ and $\mathrm{K}$ levels on paddy yield $\left(\mathrm{t} \mathrm{ha}^{-1}\right)$

\begin{tabular}{ccccc}
\hline Treatment & N0 $(0 \mathrm{~kg} / \mathrm{ha})$ & $\mathrm{N} 1(75 \mathrm{~kg} / \mathrm{ha})$ & $\mathrm{N} 2(100 \mathrm{~kg} / \mathrm{ha})$ & $\mathrm{N})$ \\
\hline $\mathrm{K} 0,0 \mathrm{~kg} / \mathrm{ha}$ & $2.44 \mathrm{c}$ & $3.62 \mathrm{a}$ & $3.68 \mathrm{a}$ & $3.14 \mathrm{~b}$ \\
\hline $\mathrm{K} 1,50 \mathrm{~kg} / \mathrm{ha}$ & $2.47 \mathrm{c}$ & $3.89 \mathrm{a}$ & $3.83 \mathrm{a}$ & $3.25 \mathrm{~b}$ \\
\hline $\mathrm{K} 2,75 \mathrm{~kg} / \mathrm{ha}$ & $2.40 \mathrm{~d}$ & $4.09 \mathrm{a}$ & $3.79 \mathrm{~b}$ & $3.34 \mathrm{c}$ \\
\hline $\mathrm{K} 3,100 \mathrm{~kg} / \mathrm{ha}$ & $2.51 \mathrm{~d}$ & $4.32 \mathrm{a}$ & $3.80 \mathrm{~b}$ & $3.48 \mathrm{c}$ \\
\hline Mean & $2.46 \mathrm{~d}$ & $3.98 \mathrm{a}$ & $3.78 \mathrm{~b}$ & $3.30 \mathrm{c}$
\end{tabular}

LSD value for $\mathrm{N}=0.14$

$\mathrm{LSD}$ value for interaction $=0.281$

LSD value for $\mathrm{K}=0.14$

Results indicated a marked increase in yield from zero $\mathrm{kg} \mathrm{N}^{-1}$ ha $100 \mathrm{~kg} \mathrm{~N}^{-1}$. This increase in yield was attributed to more number of panicle bearing tillers, more 1000 kernel weight and more number of kernels per panicle at 75 and $100 \mathrm{~kg} \mathrm{~N}$ ha $^{-1}$. This increase in yield was supported by
Chaurasia and Duvellier (2006), they found an increase in yield with increased $\mathrm{N}$ rates. Tajani et al. (1993) and Myint et al. (2007) also observed an increase in yield with increasing $\mathrm{N}$ fertilization. However, there was a significant decrease in yield

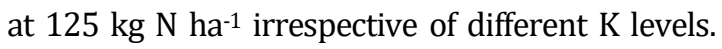
This decrease in yield may be due to high disease percentage. However, it was found no correlation between N uptake and yield of rice. Similarly,
Chaudhary et al. (2009) showed an increase in yield up to $85 \mathrm{~kg} \mathrm{~N} \mathrm{ha}^{-1}$ beyond this level decrease in yield was attributed to accumulative effect of $\mathrm{N}$ toxicity and disease severity. The yield also displayed a positive increase with increase in $\mathrm{K}$ fertilization. These results were advocated by Jayasena and Brennan (2007) and Adejumo (2010) they explained that potassium fertilization increased the yield over the control.

Table 4 Economic analysis of different application rates of $\mathrm{N}$ and $\mathrm{K}$

\begin{tabular}{|c|c|c|c|c|c|c|c|c|c|}
\hline & $\begin{array}{l}\text { Yield t } \\
\text { ha-1 }\end{array}$ & $\begin{array}{c}\text { Value Rs. } \\
\text { ha-1 }\end{array}$ & $\begin{array}{c}\text { Straw yield } t \\
\text { ha-1 }\end{array}$ & $\begin{array}{c}\text { Value Rs. } \\
\text { ha-1 }\end{array}$ & $\begin{array}{l}\text { Gross income Rs. } \\
\text { ha-1 }\end{array}$ & $\begin{array}{l}\text { Variable cost Rs. } \\
\text { ha-1 }\end{array}$ & $\begin{array}{c}\text { Total Cost } \\
\text { Rs.ha-1 }\end{array}$ & $\begin{array}{c}\text { Net Return. } \\
\text { Rs. ha-1 }\end{array}$ & $\begin{array}{c}\text { Benefit cost } \\
\text { ratio }\end{array}$ \\
\hline $\mathrm{T} 1: \mathrm{N} 1 \times \mathrm{K} 1$ & 2.44 & 79408 & 13.0 & 11011 & 90420 & 7941 & 93252 & -2832 & 0.97 \\
\hline $\mathrm{T} 2: \mathrm{N} 1 \times \mathrm{K} 2$ & 2.47 & 80167 & 13.1 & 11138 & 91305 & 15667 & 100978 & -9673 & 0.90 \\
\hline T3:N1×K3 & 2.40 & 78000 & 12.9 & 10956 & 88956 & 19275 & 104586 & -15630 & 0.85 \\
\hline $\mathrm{T} 4: \mathrm{N} 1 \times \mathrm{K} 4$ & 2.51 & 81683 & 13.6 & 11530 & 93214 & 23468 & 108779 & -15566 & 0.86 \\
\hline T5:N2×K1 & 3.62 & 117758 & 16.8 & 14312 & 132071 & 14628 & 99939 & 32131 & 1.32 \\
\hline T6:N2×K2 & 3.89 & 126533 & 17.2 & 14643 & 141176 & 23156 & 108467 & 32709 & 1.30 \\
\hline T7:N2×K3 & 4.09 & 132925 & 16.8 & 14287 & 147212 & 27620 & 112931 & 34281 & 1.30 \\
\hline T8:N2×K4 & 4.32 & 140292 & 16.9 & 14360 & 154652 & 32182 & 117493 & 37159 & 1.32 \\
\hline T9:N3×K1 & 3.68 & 119600 & 16.4 & 13926 & 133526 & 15766 & 101077 & 32449 & 1.32 \\
\hline $\mathrm{T} 10: \mathrm{N} 3 \times \mathrm{K} 2$ & 3.83 & 124583 & 16.7 & 14226 & 138810 & 23915 & 109226 & 29584 & 1.27 \\
\hline T11:N3×K3 & 3.79 & 123067 & 17.2 & 14653 & 137719 & 27588 & 112899 & 24820 & 1.22 \\
\hline T12:N3×K4 & 3.80 & 123608 & 16.8 & 14295 & 137904 & 31467 & 116778 & 21126 & 1.18 \\
\hline T13:N4×K1 & 3.14 & 102158 & 15.9 & 13528 & 115686 & 14967 & 100278 & 15408 & 1.15 \\
\hline T14:N4×K2 & 3.25 & 105733 & 15.8 & 13431 & 119164 & 22975 & 108286 & 10878 & 1.10 \\
\hline T15:N4×K3 & 3.34 & 108550 & 16.2 & 13749 & 122299 & 27081 & 112392 & 9907 & 1.09 \\
\hline T16:N4×K4 & 3.48 & 113100 & 16.9 & 14339 & 127439 & 31361 & 116672 & 10767 & 1.09 \\
\hline
\end{tabular}


Fixed cost Rs. per ha ${ }^{-1} \quad=85311.0$

Paddy price Rs. per $40 \mathrm{~kg}=1300.0$

$\mathrm{N}_{1}: 0 \mathrm{~kg} \mathrm{~N}^{-1}=0$ bags of Urea

$\mathrm{N}_{2}: 75 \mathrm{~kg} \mathrm{~N} \mathrm{ha}^{-1}=3.26$ bags of Urea

$\mathrm{N}_{3}: 100 \mathrm{~kg} \mathrm{~N} \mathrm{ha}^{-1}=4.35$ bags of Urea

$\mathrm{N}_{4}: 125 \mathrm{~kg} \mathrm{~N} \mathrm{ha}^{-1}=5.43$ bags of Urea

\section{ECONOMIC ANALYSIS}

The effectiveness of any production system is ultimately evaluated on the basis of it's economics. Economic analysis is criteria for basic determination of net benefits. The economic analysis for different $\mathrm{N}$ and $\mathrm{K}$ rates is essential to evaluate results from farmer point of view as they are more interested in net return or benefit. In the economic analysis of present study price of inputs and outputs prevailing in the local market of Faisalabad (Pakistan) was used to calculate the budget of treatments (Table 4).

The gross income was calculated by adding paddy and straw yield values per hectare. Paddy price was Rs. 32500 ton $^{-1}$ and straw price of Rs. 700 ton $^{-1}$. The complete budget (2010) presented in Table 4.16 revealed that application of $75 \mathrm{~kg} \mathrm{~N}$ and $100 \mathrm{~kg} \mathrm{~K} \mathrm{ha}^{-1}$ gave maximum net returns amounting Rs. 37159, whereas the highest cost benefit ratio (BCR) of 1.32 was obtained in treatments T8 (75 kg N and $100 \mathrm{~kg} \mathrm{~K} \mathrm{ha-)}$ and T9 (100 kg N and $0 \mathrm{~kg} \mathrm{~K} \mathrm{ha-).} \mathrm{The} \mathrm{production} \mathrm{level}$ at $\mathrm{T} 8$ is favored for lower disease severity.

\section{CONCLUSION}

BLB responded significantly to different levels of $\mathrm{N}$ and $\mathrm{K}$ fertilizers. Both deficiency and excessive use of $\mathrm{N}$ promoted disease severity. Lower diseased leaf area $(\%$ DLA) was observed where $\mathrm{N}$ was applied at the rate of 75-100 kg ha-1. Results revealed that balanced nutrition is required to manage the BLB problem. As the rate of $\mathrm{N}$ fertilizer was increased the demand for potassium also increased. Super Basmati gave best paddy yield, highest harvest index value, higher gross income, maximum net returns, higher benefit cost ratio and provide more protection against BLB when fertilized @ 75 kg N \& 100 kg Kha ${ }^{-1}$.

\section{REFERENCES}

Adejumo, C. O. 2010. Promoting artistic and cultural development through service learning and critical pedagogy in a low-income community art program. Visual arts research, 36: 23-34.

Chaudhary, S. U., M. Hussain, J. Iqbal and M. A. Ali. 2009. Effect of nitrogen doses on incidence of bacterial leaf blight in rice. Journal of Agricultural Research, 47.

Davierwala, A., A. Reddy, M. Lagu, P. Ranjekar and V. Gupta. 2001. Marker assisted selection of bacterial blight resistance genes in rice. Biochemical genetics, 39: 261-278.

GOP. 2010. Economic survey of Pakistan, 2010. Ministry of Food, Agriculture and Livestock Division (Economic Wing). Islamabad, pp. 22-23.

Gothoskar, S. S., R. P. Scheffer, J. C. Walker and M. A. Stahmann. 1995. The role of enzymes in the development of Fusarium wilt of tomato. Indian Phytopathology: 381-387.

Harris, G. 1997. Potassium deficiency in cotton linked to leafspot disease. Better Crops, 81: 10-11.

IRRI. 2004. International Rice Research Institute "Rice", Almanac. 3rd Edition ed. Int. Rice Res. Inst, Los, Banos, Philippines, pp. 59-235.

Jayasena, K. and R. Brennan. 2007. Potassium deficient barley is more susceptible to powdery mildew disease.

Krupinsky, J. M., D. L. Tanaka, S. D. Merrill, M. A. Liebig, M. T. Lares and J. D. Hanson. 2007. Crop Sequence Effects on Leaf Spot Diseases of No-Till Spring Wheat. Agronomy Journal, 99: 912.

Kürschner, E. 1992. Effects of Nitrogen Timing and Split Application on Blast Disease in Upland Rice. Plant Disease, 76: 384.

Long, D. H., F. N. Lee and D. O. TeBeest. 2000. Effect of Nitrogen Fertilization on Disease Progress of Rice Blast on Susceptible and Resistant Cultivars. Plant Disease, 84: 403-409.

Magen, H. 2008. Balanced crop nutrition: fertilizing for crop and food quality. Turkish Journal of Agriculture and Forestry, 32: 183-193.

Mary, C. and J. Mathew. 1983. Chemical control of bacterial leaf blight of rice using antibiotics. Agricultural Research Journal of Kerala, 21: 17-20.

Matho, R. and D. Ganguly. 2001. Heterosis and combining ability studies in maize. Journal of Research, 13: 197-199. 
Myint, S. S., K. M. Nyunt, H. K. Ko and M. M. Thein. 2007. Study on the Effect of Different Urea Fertilizer Rates and Plant Populations on the Severity of Bacterial Blight (BB) of Rice. Journal of Agriculture and Rural Development in the Tropics and Subtropics (JARTS), 108: 161-167.

Prabhu, A. S., M. P. Barbosa Filho, M. C. Filippi and F. J. P. Zimmermann. 1999. Relationship between potassium fertilization and panicle blast severity in upland rice. Pesquisa Agropecuária Brasileira, 34: 1729-1732.

Reissing, W., E. Heinrich, I. Listinger and A. Barrian. 1986. Illustrated Guide to Integrated Pest Management in Rice. Tropical Asia IRRI, Manaila Philippines.

Sharma, P. 2007. Vegetables: Disease, Diagnosis and Biomanagement. Aavishkar Publishers, Distributors.
Steel, R., J. Torrie and D. Dickey. 1997. Principles and Procedures of Statistics. A Biometrical Approach. 3rd Ed ed. McGraw Hill Book Co, New York.

Tajani, M., A. Douira, N. Haloui and R. Benkirane. 1993. Impact of fertilization on disease development and yield components. Cahiers Options Mediterraneennes, 3: 95-99.

Waller, J. M. 1987. Rice Diseases. By S. H. Ou Slough, UK: Commonwealth Agricultural Bureaux (1985) 2nd ed., pp. 380, UK $£ 38.00$, USA \$70, elsewhere $£ 41.00$. Experimental Agriculture, 23: 357.

Williams, J. and S. G. Smith. 2001. Correcting potassium deficiency can reduce rice stem diseases. Better crops, 85: 7-9.

$\mathrm{Wu}, \mathrm{J}$. R. X. and R. Härdter. 2000. Balanced plant nutrition may help re duce pesticide use by improving tea plants' resistance to fungal diseases. 